\title{
Isolation of Onopordopicrin, the Toxic Constituent of Arctium lappa L
}

\author{
José Maria Barbosa-Filho* \\ Laboratório de Tecnologia Farmacêutica - UFPB \\ 58059-900 João Pessoa, PB, Brasil \\ Mirtes Costa, Cecília Gomes and Gustaf Trolin \\ Departamento de Farmacologia, Escola Paulista de Medicina, \\ 04023-062 São Paulo, SP, Brasil
}

Received: june 22, 1992; november 23, 1993.

\begin{abstract}
Através de monitoração da atividade tóxica em camundongos foi isolado das folhas de Arctium lappa, uma lactona sesquiterpênica identificada como onopordopicrina.

A sesquiterpene lactone, identified as onopordopicrin, was isolated from the leaves of Arctium lappa, with the aid of monitoring the toxic activity of the extracts in mice.
\end{abstract}

Key words: Arctium lappa; sesquiterpene lactone; onopordopicrin.

\section{Introduction}

Arctium lappa L. (family Asteraceae, tribe Cynareae) known as "bardana" in Brazil, is used for its diuretic and antiseptic properties (leaf and root) while the root is also used for edible purposes ${ }^{1}$. During the purification of a toxic substance found in this species ${ }^{2}$, a fraction containing a sesquiterpene lactone was isolated. This sesquiterpene containing active fraction was obtained by extraction of the fresh leaves $(5 \% \mathrm{w} / \mathrm{v})$ in $70 \%$ aqueous ethanol, followed by concentration and extraction with diethyl ether. The ether fraction was evaporated and taken up in $60 \%$ aqueous methanol, which was then extracted with hexane and chloroform respectively. The toxic activity was found in the chloroform extract; its chromatography resulted in the isolation of the active component identified as the sesquiterpene lactone onopordopicrin by comparing $[\alpha] \mathrm{D}, \mathrm{uv}, \mathrm{ir}, \mathrm{ms},{ }^{1} \mathrm{HNMR}$ data with those given in the literature ${ }^{3-5}$. The ${ }^{13} \mathrm{C} N \mathrm{NM}$ values (Table 1), are consistent with the structure reported ${ }^{3}$.

Onopordopicrin is the major constituent of all previously studied species of Onopordon ${ }^{3-8}$, with occasional appearance in some species of other genera ${ }^{9}$.

\section{Experimental}

Materials. The plant material was collected from an area $60 \mathrm{~km}$ away from São Paulo, authenticated by Drs. S.J.L.Mendacolli and M. Kirizawa, Instituto Botânico de São Paulo, where the voucher specimen was deposited (SP 238.570)., The uv spectra were determined on a Specord

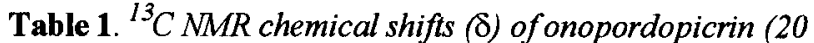
$\mathrm{MHz}, \mathrm{CDCl}_{3}, \mathrm{TMS}$ as internal standard)*

\begin{tabular}{rrrr}
\multicolumn{2}{c}{ Carbon } & \multicolumn{3}{c}{ Onopordopicrin(APT) } \\
1 & $130.0(\mathrm{n})$ & 11 & $132.2(\mathrm{p})$ \\
2 & $26.2(\mathrm{p})$ & 12 & $165.3(\mathrm{p})$ \\
3 & $34.6(\mathrm{p})$ & 13 & $125.4(\mathrm{p})$ \\
4 & $144.4(\mathrm{p})$ & 14 & $16.9(\mathrm{n})$ \\
5 & $128.4(\mathrm{n})$ & 15 & $60.9(\mathrm{p})$ \\
6 & $77.0(\mathrm{n})$ & $1^{\prime}$ & $170.3(\mathrm{p})$ \\
7 & $53.0(\mathrm{n})$ & $2^{\prime}$ & $135.5(\mathrm{p})$ \\
8 & $73.2(\mathrm{n})$ & $3^{\prime}$ & $126.1(\mathrm{p})$ \\
9 & $48.6(\mathrm{p})$ & $4^{\prime}$ & $61.6(\mathrm{p})$ \\
10 & $139.7(\mathrm{p})$ & &
\end{tabular}

* An attached proton test spectrum was also recorded for onopordopicrin and the results are given in parentheses in which $p=$ positive signal (with two or no protons attached); $n=$ negative signal (with one or three protons attached).

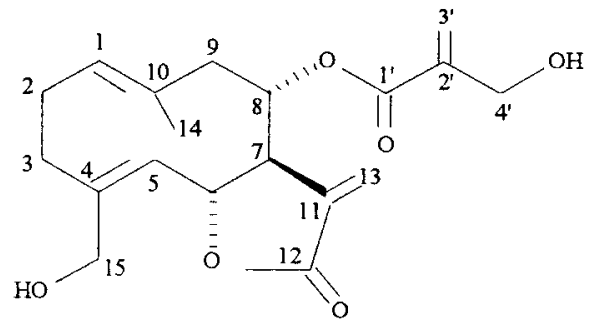


UV-VIS Jena spectrophotometer, and ir spectra were obtained on a Perkin Elmer 467 grating spectrophotometer. Low resolution mass spectra were obtained on a Micro Mass-12 instrument operating at $70 \mathrm{eV}$. The ${ }^{1} \mathrm{H} N M R$ and ${ }^{13} \mathrm{C} \mathrm{NMR}$ spectra were recorded on a Varian FT-80A spectrometer. Silica gel 60 (E. Merck) was used for column chromatography and silica gel 60 PF254 for preparative tlc.

Isolation ofonopordopicrin. Fresh leaves $(1 \mathrm{~kg})$ of $A$. lappa were percolated with $70 \% \mathrm{EtOH}$ at room temperature. The solution was concentrated in vacuo to furnish a residue $98 \mathrm{~g}$ ). The residue dryness $(41 \mathrm{~g})$ showed toxic activity. It was suspended in $60 \% \mathrm{MeOH}$ and washed successively with n-hexane and chloroform. The $\mathrm{CHCl}_{3}$ residue (16 g) which showed activity was submitted to column chromatography on silica gel $(300 \mathrm{~g})$ using eluents of increasing polarity: $\mathrm{CHCl}_{3}$ (fr. 1-12), $\mathrm{CHCl}_{3}-\mathrm{MeOH}$ 9.9:0.1 (fr. 13-15), $\mathrm{CHCl}_{3}-\mathrm{MeOH}$ 9.8:0.2 (fr. 16-19), $\mathrm{CHCl}_{3}-\mathrm{MeOH}$ 9.6:0.4 (fr. 20-35), $\mathrm{CHCl}_{3}$ $\mathrm{MeOH}$ 9.4:0.6 (fr. 36-40), $\mathrm{CHCl}_{3}-\mathrm{MeOH} 9.0: 1.0$ (fr. 41-42). Evaporation of each fraction left a residue which was tested for toxicity. The most toxic fraction (20-35) (1 g) was submitted to preparative tic and onopordopicrin $(0.8 \mathrm{~g})$ was identified by its physical properties.

\section{Acknowledgements}

This work was supported by CNPq. We thank Prof. D. F. Medeiros for encouragement, Mrs. Dulce Gonçalves de Oliveira and Cleomar de Souza Ferreira for Technical Assistance.

\section{References}

1. M.P. Corrêa, "Dicionário das Plantas Úteis do Brasil e das Exóticas Cultivadas", Ministério da Agricultura, IBDF, 1984, Vol. 1, p. 265.

2. M. Costa, "Identificação e farmacologia geral da substôncia tóxica isolada de Arctium Lappa L. (Asteraceae)", M. Sc. Thesis, Escola Paulsita de Medicina, Brasil (1991).

3. B. Drozdz, M. Holub, S. Samek, V. Herout, F. Sorm, Collect. Czech. Chem. Commun. 33, 1730 (1968).

4. S.M. Khafagy, A.M.Metwally, A. A. Omar, Pharmazie 32, 123 (1977)

5. A. Rustaiyan, L. Nazarians, F. Bolmnn, Phytochemistry 18, 879 (1979).

6. A. Rustaiyan, L. Nazarians, F. Bolmnn, Phytochemistry 18, 883 (1979)

7. A. Rustaiyan, B. Ahmadi, J. Jakupovic, F. Bohlmann, Phytochemistry 25, 1659 (1986).

8. M. Miski, A. H. Mericli, T. J. Marbry, Phytochemistry 27, 1417 (1988).

9. A. G. Gonzalez, J. M. Arteaga, J. L. Breton, Phytochemistry 12, 2977 (1973). 